\title{
OVERCOMING THE HURDLE OF FIRST COST: ACTION RESEARCH IN TARGET COSTING
}

\author{
Glenn Ballard $^{1 *}$ and Zofia K. Rybkowski ${ }^{2}$ \\ ${ }^{1}$ Research Director, Project Production Systems Laboratory, http://p2sl.berkeley.edu/ \\ Adjunct Associate Professor, Department of Civil and Environmental Engineering \\ 214 McLaughlin Hall, University of California, Berkeley, CA 94720-1712 \\ Phone+1 510/530-1743, ballard@ce.berkeley.edu \\ $2 \mathrm{PhD}$ Candidate, Program in Engineering and Project Management \\ Department of Civil and Environmental Engineering, 215-A McLaughlin Hall \\ University of California, Berkeley, CA 94720-1712 \\ Phone+1510/684-5729, cezkr@berkeley.edu
}

\begin{abstract}
Advocates of sustainable and evidence-based design initiatives argue that building owners can secure favorable internal rates of return when full life cycle building costs are considered. While the argument has merit, these decision-makers express concern about overcoming the hurdle of first cost. To reduce first cost, a number of lean construction practitioners are exploring a planning and design process called target costing. Target costing in construction is a collaborative cost management process that relies on business plan validation to determine what is to be delivered and what the client is willing and able to pay for a project - before establishing the allowable cost. When warranted, a target cost may be set even lower than the allowable cost in order to spur innovation. Once a target cost has been established, the project is collaboratively designed to that target cost. This case study examines the target costing techniques used during the design of an 850,000 square foot (approximately 79,000 square meters) medical center. Qualitative and quantitative outcomes are explored, as well as implications for future projects.
\end{abstract}

\section{INTRODUCTION}

A number of building designers argue that higher quality facilities can lead to longterm cost savings, an assertion that is especially developing momentum among sustainable design communities, as well as among those active in the evidence-based design (EBD) movement. Long term cost savings are calculated using a technique known as Life Cycle Cost Analysis (LCCA). The methodology can be applied when periodic savings from reduced use of energy, water or operation and maintenance 
costs (in the case of sustainable design) or medicinal or legal costs, for example (in the case of EBD), result in a calculation of positive net present value (NPV) (Boussabaine and Kirkham 2004; Bull 1993; Evans et al. 1998; Ive 2006; Kirk and Dell'Isola 1995). Such attempts to bolster the quality of decision-making have merit; it makes intuitive sense that improved facility quality can lead to reduced need for facility maintenance and replacement over time. However, skeptics argue a number of hurdles must be overcome in order to construct a higher quality building. For example, the pay-now-save-later expectation of LCCA makes it limited in its applicability because building owners wishing to construct a higher quality facility are still constrained by their ability to finance the project, a reality with which they must contend, irrespective of long-term benefits. In other words, first cost - or the capital investment cost that is expended on a facility when it is constructed-often becomes a significant challenge that trumps positive NPV calculations (Ashworth 1993; Cole and Sterner 2000; Moore 2001).

The constraint of first cost must therefore be addressed if LCCA is ever to become a viable tool for capital budgeters to use. Leaders of lean construction have suggested that first cost can be made more manageable if building design teams apply principles of target costing during the design process (Ballard and Reiser 2004; Macomber et al. 2008; Nicolini et al. 2000).

\section{Target Costing}

According to Cooper and Slagmulder (1997), "target costing is a disciplined process for determining and realizing a total cost at which a proposed product with specified functionality must be produced to generate the desired profitability at its anticipated selling price in the future." In traditional product pricing, the price of a product is established by adding a profit markup to the cost required to produce the product. The problem with this method is there is no guarantee that buyers will be willing to pay the asking price. The process of target costing, by contrast, engages a reverse strategy; the market price is first established by determining how much buyers might be willing to pay (using focus group research, for example). A desired profit is then subtracted to give product designers the cost to which they must design the product:

\section{Target cost $=$ Target Price (revenues) - Target Margin $\quad($ Clifton et al. 2004)}

The word "must" is emphasized in the definition of target costing, suggesting that, if the product cannot be designed and produced at the required cost, the project must be abandoned (Clifton et al. 2004). This stipulation is the only way to ensure that the product will ultimately be profitable.

Assuring the economic validity of construction projects is much needed. Cost overruns are commonplace and the traditional practice of costing a design rather than designing to cost often leads to cost cutting measures, such as late stage value engineering and a scramble to reduce specifications, quality and profit (Nicolini et al. 2000). The system sets suppliers and service providers against the owner, removing any incentive to streamline costs early on. In fact, cost reduction measures are typically introduced so late in the design process that they have led to diminished functionality, giving value engineering a dubious reputation in the industry. 
By contrast, target costing begins with a business plan, as well as business plan validation. In combination, these project definition stages help owners identify what they are able and willing to pay for their proposed facility. The process of target costing is performed early using cross-functional teams, where the owner, service providers and suppliers function collaboratively (Ballard 2006; Ballard 2008; Ballard and Reiser 2004; Clifton et al. 2004; Nicolini et al. 2000). Focusing on collaboration and long-standing relationships, team members work creatively to value engineer individual subsystems, with the target cost and program as its ultimate goal (Ahuja and Walsh 1983; Barrie and Paulson 1992; Cooper and Slagmulder 1997; Fisk 2003; Nicolini et al. 2000).

Again, it is crucial that target costing takes place throughout the development of a project's design, when ability to impact cost is greatest, as has been suggested by a number of architecture, engineering and construction professionals (MSA 2004; Paulson 1976). This enables cost savings without sacrificing functionality to the same extent that occurs during late stage value engineering.

\section{Target Costing in Construction}

Target costing in construction has been "broadened to include additional design criteria beyond cost, including time, work scheduling, buildability and similar issues." (Ballard and Reiser 2004; Lichtig 2005). A pioneering paper by Nicolini et al (2000) bridged the gap between target costing for product design and target costing for building design. Unfortunately, the case study they reported was unsuccessful. The first successful application of target costing in construction appears to have been the case reported in Ballard and Reiser (2004), in which a college athletic field house was designed and built for a cost per square foot 30\% lower and 10 months shorter in project duration, compared to a comparable project on which target costing had not been used.

Target costing in construction applies most readily to developers producing something for sale or lease to others and to clients producing their own means of production (Ballard 2008). The developer estimates the returns from sale or lease of a facility, specifies an acceptable profit margin, then calculates the allowable cost for producing the facility. Clients producing facilities for their own use similarly estimate the benefits from the investment (equivalent to revenues), specify an acceptable return, and then calculate the allowable cost (i.e., what they are able and willing to spend to get those benefits). Because of the complexity of buildings and their cost uncertainty, Ballard argues that key design and construction professionals should be engaged by clients in a business validation phase. Including a separate building validation phase ensures alignment of ends, means and constraints (Ballard 2008). Again, the target costing process demands that a building which cannot be realized at or below target cost should not be built. By involving the key members of the project team, designers and builders, in business plan validation, an owner is able to terminate development of an unfeasible project early enough in the process, minimizing loss.

The Project Production Systems Laboratory at the University of California, Berkeley, published a current best practice guide to target costing in November, 2005 (P2SL 2005). The process steps recommended were: 
1. The client evaluates the business case and decides whether or not to fund a feasibility study.

2. The feasibility study involves all key members (designers, constructors, and client stakeholders) of the team that will deliver the project if the study findings are positive.

3. The client is an active and permanent member of the project delivery team.

4. The feasibility study produces a detailed budget aligned with scope.

5. All team members understand the business case and stakeholder values.

6. A cardinal rule is agreed upon by all performers: the Target Cost cannot be exceeded.

7. Cost estimating and budgeting is done continuously (i.e. "over-the-shoulder estimating") through intimate collaboration between design professionals and cost modelers.

8. The Last Planner system is used to coordinate the actions of team members.

The next section discusses the methodology used during this action research project. In addition to the P2SL components, the project also introduced a new form of contract, the Integrated Form of Agreement.

\section{METHODOLOGY}

The authors chose to document the target costing process of an 850,000 square foot U.S.-based medical center using action research. Because the practice of construction target costing is still developing and because implementation requires participation and exploration by all members of the project team (Greenwood et al. 1993), it was decided that action research was the most appropriate methodology to use for research of this nature. Action research can document a single project, but differs from more familiar case study research in that "the researcher is not an independent observer, but becomes a participant, and the process of change becomes the subject of research" (Benbasat et al. 1987; Westbrook 1995).

As mentioned above, the project adopted an Integrated Form of Agreement (IFOA). Construction contracts that subordinate the interests of one party to another or distribute risk unevenly are common in the construction industry and have been blamed for high levels of distrust and litigation. Conversely, when a contract supports risk sharing, as does the IFOA, individual parties identify their own interests with that of the project (Koskela et al. 2006; Lichtig 2006). The IFOA contract also allows money to move across organizational boundaries in search of the optimal life cycle cost investment. Such a contract was utilized throughout the action research project.

The target cost was established during an extensive business planning phase, followed by a four month business plan validation phase that included key members of the project design team: architect, engineer, contractor and critical trade partners.

During the entire twelve month of designing to targets, team members physically co-located to the same office floor (figure 1). The co-located team included the contractor, as well as representatives from the mechanical, plumbing and electrical (5 days/week), curtain wall, architectural metal panels, shoring, elevator, 
drywall, structural steel and concrete trade partners (2-3 days per week). To enhance communication, members from a single company sat in multiple groups; for example, architectural representatives sat in the sustainability, planning, exterior enclosure, interiors, administration and technical architect groups.

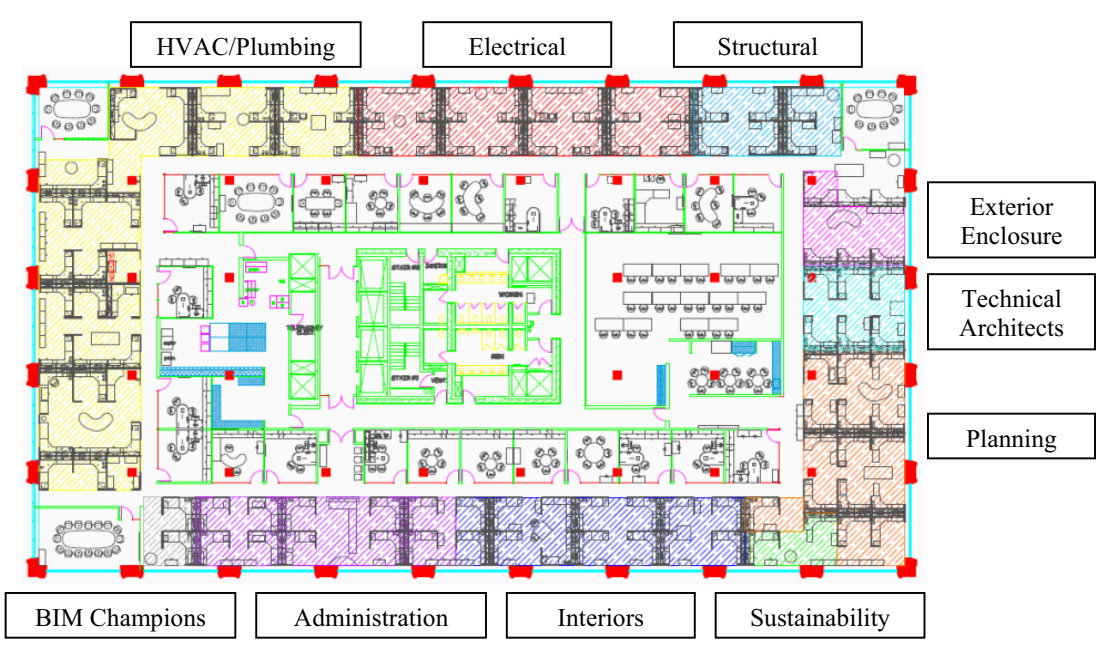

Figure 1. Cluster groups were physically co-located on the same floor.

Trade contractors were referred to as "trade partners" to more accurately reflect their role as integral contributors during the preconstruction and construction phases of target costing exercises. All existing team members and trade partners were permitted to interview new members under consideration and were permitted an equal voice during the hiring process.

The target costing process is meeting intensive. The project team met in a big room for approximately two hours each meeting, two times per week-once for a target costing exercise and once for a Last Planner exercise (Last Planner ${ }^{\mathrm{TM}}$ is a lean project planning and control system (Ballard 2000; Hamzeh et al. 2008)).

Planning and preplanning of individual parts of the project were generally accomplished during cluster group and subcommittee meetings. Each cluster group was assigned its own target cost to meet. Value engineering changes recommended by one group were circulated to all others to determine the cost implications on the entire project. Cluster Groups for this project included structural, mechanical, electrical and plumbing, exterior skin (architectural enclosure), interiors, project requirements, site work, and conveying systems. In addition to meeting with the entire project team twice weekly as previously described, Cluster Groups individually met 2-3 hours per week; these meetings were scheduled not to overlap, so that team members could attend other Cluster Group meetings, as needed. Representatives 
from a single company would inhabit multiple Cluster Groups. Additionally, a Core Group met regularly, and included executive representation from the owner, architect, contractor and concrete trade partner.

Because a successful target costing process requires them to engage in practices with which they may not be familiar, team members were continually trained in lean production thinking and met regularly to read and discuss chapters from Jeffrey Liker's The Toyota Way (Liker 2004).

To benchmark the team's progress toward its target cost goal, the estimating manager weekly presented a current estimate plot so the entire team could monitor its current position vis-à-vis the target cost (figure 2). To better identify innovation and cost savings on a regular basis, material escalations were updated every 6 months and labor escalations every 12 months. Target costing goals were established for each building subsystem to motivate each Cluster Group to brainstorm innovative and unique cost saving opportunities using its own methods. For example, although the structural engineering group used building information modeling (BIM) to regularly update its estimates, the architecture group used 2D electronic estimating methods.

Set-based design is a process in which design alternatives are defined and communicated between all disciplines, and choosing a single alternative is done at the last responsible moment. This occurs at each level of design development; from concept to detailed design (Parrish et al. 2008a; b). The process reduces the waste that accompanies negative iteration-iteration that does not add value to the design. Individual members of the project team used A-3 sized sheets of paper to document and post - for all to see and evaluate-design alternatives they recommended the owner consider adopting.

Although the project maintained a central intranet site with current drawings, updated drawing sets were regularly printed and posted on designated walls at the project office to reduce the waste and confusion that sometimes occurs when individual team members print their own sets.

To ensure a spirit of continual improvement, a plus/delta exercise was used following meetings. Plus/delta is a process advocated by the Lean Construction Institute. A flip chart is divided into two columns: a "+" sign heads the left column and a " $\Delta$ " sign heads that on the right. Unlike the more familiar category of ".", " $\Delta$ " represents "opportunity for change or improvement." The distinction is important because it diverts team attention away from blame-finding or finger pointing and focuses it on it instead on opportunities for continual improvement $-\mathrm{a}$ fundamental tenet of lean.

\section{RESULTS}

Results from the target costing process for the case study medical facility are shown in figure 2. Note that progress toward the target cost was gradual, but steady, trending down over time, in contrast to the more typical increase in cost estimates as drawings increase in complexity.

During the initial twelve months design development (9/07-07/08), the team reduced its estimate from an initial anticipated total cost of over $\$ 970$ million by $\$ 85$ million (the final goal is a reduction of more than $\$ 90$ million). To achieve this reduction, the project team generated design alternatives that were thoroughly tested 
before incorporation into the cost estimate. According to the project estimator, physical co-location of the project team and the twice per week big room meetings brought the greatest benefit to the target costing exercise. This communication is said to have greatly saved time associated with traditional design-bid-build contractual communication.

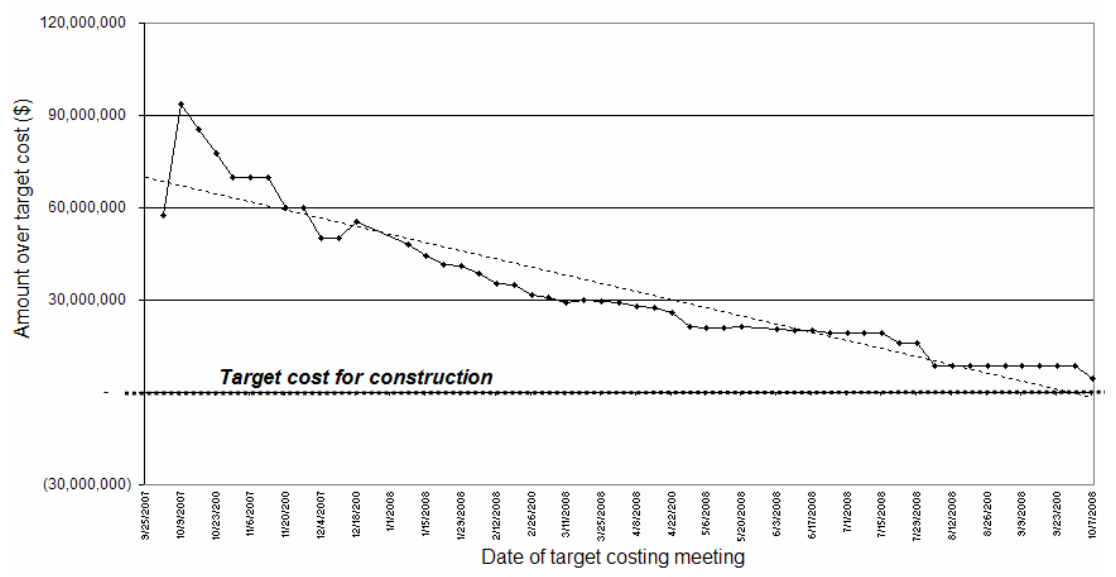

Figure 2. Target costing progression over development of project. Vertical axis represents the remaining gap between the current estimate and the target cost.

Some examples of design innovations that helped reduce expected cost:

- Changed building mass to accommodate program fit

- Modified elevator design

- Increased efficiency of plumbing, HVAC, elevator

- Increased efficiency of structure, switching parking framing from concrete to steel

- Redesigned switchgear

- Modified exterior skin design 


\section{DISCUSSION}

Quantifying the impact of construction target costing is still in its early days. Quantification usually demands controlled scientific experimentation, where confounding variables are eliminated by holding all variables constant but one (Bernard 2000). However, the complexity of construction processes renders more traditional research methods impractical. Action research methodology is suited to case study situations in which multiple variables impact a process and researchers effect change. In this project, researchers helped facilitate the experimental target costing process.

Target costing is of special interest to these authors in the context of life cycle cost analysis (LCCA). LCCA tools help owners determine payback periods or engage in cost-benefit analysis when making decisions about whether or not to invest in an environmentally sustainable building system or when contemplating the inclusion of Evidence-Based Design interventions in a medical facility. While the results of LCCA might recommend investment in a sustainable energy system (given long term annual energy savings), for example, many owners are put in the position of not being able to afford the requisite capital—or "first"— cost. Early work on target costing case studies has been promising. It is hoped that additional action research experiments will build on work currently being done.

\section{CONCLUSION}

Construction target costing offers an opportunity to substantially reduce first cost without compromising the required functionality of a facility. Used in combination with lean principles and the Last Planner System of project management, preliminary results show that an integrated project delivery team for an 850,000 square foot California-based medical facility has been able to successfully achieve a target cost $14 \%$ below market, reducing its initial cost estimate by $9 \%$ by incorporating design innovations.

\section{ACKNOWLEDGMENTS}

Research for this paper was in part supported by gifts made to the Project Production Systems Laboratory (http://p2sl.berkeley.edu/). All support is gratefully acknowledged. Any opinions, findings, conclusions, or recommendations expressed in this paper are those of the authors and do not necessarily reflect the views of the Project Production Systems Laboratory.

\section{REFERENCES}

Ahuja, H. N., and Walsh, M. A., eds. (1983). Successful methods in cost engineering, Wiley, New York.

Ashworth, A. (1993). "How life cycle costing could have improved existing costing." In: Life Cycle Costing for Construction, J. W. Bull, ed., Blackie Academic \& Professional, London. 
Ballard, G. (2006). "Rethinking project definition in terms of target costing." Proceedings IGLC-14, Santiago, Chile, 77-89.

Ballard, G. (2008). "The lean project delivery system: an update." 1-19. www.leanconstructionjournal.org

Ballard, G., and Reiser, P. (2004). "The St. Olaf College Fieldhouse Project: a Case Study in Designing to Target Cost." 12th Annual Conference of the International Group for Lean Construction, Elsinor, Denmark, 234-249.

Ballard, H. G. (2000). "The Last Planner System of Production Control," The University of Birmingham, Birmingham, UK.

Barrie, D. S., and Paulson, B. C. (1992). Professional Construction Management: including CM, Design-Construct, and General Contracting, McGraw-Hill, Inc., New York.

Benbasat, I., Goldstein, D. K., and Mead, M. (1987). "The case research strategy in studies of information systems." MIS Quarterly, 369-386.

Bernard, H. R. (2000). Social Research Methods: Qualitative and Quantitative Approaches, Sage Publications, Inc., Thousand Oaks.

Boussabaine, A., and Kirkham, R. (2004). Whole Life-Cycle Costing, Blackwell Publishing, Bodmin, Cornwall.

Bull, J. W. (1993). Life Cycle Costing for Construction, Blackie Academic \& Professional, London.

Clifton, M. B., Bird, H. M. B., Albano, R. E., and Townsend, W. P. (2004). Target Costing: Market-Driven Product Design, Marcel Dekker, Inc., New York.

Cole, R. J., and Sterner, E. (2000). "Reconciling theory and practice of life-cycle costing." Building Research \& Information, 28(5/6), 368-375.

Cooper, R., and Slagmulder, R. (1997). Target Costing and Value Engineering, Productivity Press, Portland, UK.

Evans, R., Haryott, R., Haste, N., and Jones, A. (1998). "The long term costs of owning and using buildings." Royal Academy of Engineering, London.

Fisk, E. R. (2003). Construction Project Administration, Prentice Hall, Upper Saddle River, N.J.

Greenwood, D. J., Whyte, W. F., and Harkavy, I. (1993). "Participatory action research as a process and as a goal." Human Relations, 46, 175-191.

Hamzeh, F. R., Ballard, G., and Tommelein, I. D. (2008). "Improving Construction Work Flow--the Connective Role of Lookahead Planning." Proceedings for the 16th Annual Conference of the International Group for Lean Construction, Manchester, UK, 635-646.

Ive, G. (2006). "Re-examining the costs and value ratios of owning and occupying buildings." Building Research \& Information, 34(3), 230-245.

Kirk, S. J., and Dell'Isola, A. J. (1995). Life Cycle Costing for Design Professionals, McGraw-Hill, Inc., New York.

Koskela, L., Howell, G., and Lichtig, W. (2006). "Contracts and production." CIB W92 Symposium on Sustainability and Value through Construction Procurement, Salford, UK, 332-229.

Lichtig, W. A. (2005). "Ten key decisions to a successful construction project." American Bar Association Forum on the Construction Industry, Toronto, Canada, 1-26. 
Lichtig, W. A. (2006). "The Integrated Agreement for Lean Project Delivery." Construction Lawyer, 26(3).

Liker, J. (2004). The Toyota Way: 14 Management Principles from the World's Greatest Manufacturer, McGraw-Hill, New York.

Macomber, H., Howell, G., and Barberio, J. (2008). "Target-Value Design: Nine Foundational Practices for Delivering Surprising Client Value." $<$ http://www.aia.org/nwsltr pm.cfm?pagename=pm a 112007 targetvaluede

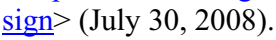

Moore, R. (2001). "Management side of engineering: payback method--too simple and too expensive." Plant Engineering.

MSA. (2004). "MacLeamy Curve." < $<$ http://www.msa-ipd.com/MacleamyCurve.pdf $>$ (July 30, 2008).

Nicolini, D., Tomkins, C., Holti, R., Oldman, A., and Smalley, M. (2000). "Can Target Costing and Whole Life Costing be applied to the Construction Industry? Evidence from Two Case Studies." British Journal of Management, $11,303-324$.

P2SL. (2005). "P2SL Report on the Current Benchmark in Target Costing." Project Production Systems Laboratory, University of California, Berkeley. p2sl.berkeley.edu

Parrish, K., Wong, J.-M., Tommelein, I. D., and Stojadinovic, B. (2008a). "Set-based design: case study on innovative hospital design." Proceedings for the 16th Annual Conference of the International Group for Lean Construction, Manchester, UK, 413-423.

Parrish, K., Wong, J.-M., Tommelein, I. D., and Stojadinovic, B. (2008b). "Value propositions for set-based design of reinforced concrete structures." Proceedings for the 16th Annual Conference of the International Group for Lean Construction, Manchester, UK, 495-506.

Paulson, B. C., Jr. (1976). "Designing to reduce construction costs." Journal of the Construction Division, ASCE, 102(CO4).

Westbrook, R. (1995). "Action research: a new paradigm for research in production and operations management." International Journal of Operations \& Productions Management, 15(12), 6-20. 